\title{
Sonografi Destekli Yorumlama: Semptomatik Çocuklarda İnsidental Bulunan Mezenterik Lenfadenitin Anlamı Var Mı?
}

\section{Sonography-Assisted Interpretation: Is There Any Meaning of Mesenteric Lymphadenitis Found Incidentally in Symptomatic Children?}

\author{
Avni Merter Keçeli ${ }^{*}$, Zeynep Keskin² \\ ${ }^{1}$ Konya Şehir Hastanesi Radyoloji, Pediatrik Radyoloji Bölümü, Konya, Türkiye. \\ ${ }^{2}$ Konya Şehir Hastanesi Radyoloji Bölümü, Konya, Türkiye. \\ e-mail: merterkeceli@gmail.com,zkeskin@ymail.com \\ Orcid: 0000-0002-9412-6733 \\ Orcid: 0000-0001-6496-8748 \\ *Sorumlu Yazar / Corresponding Author: Sorumlu Yazar: Avni Merter Keçeli \\ Gönderim Tarihi / Received: 12.03.2021 \\ Kabul Tarihi / Accepted: 02.06.2021 \\ DOI: $10.34087 /$ cbusbed. 895382
}

Giriş ve Amaç: Karın ağrısı nedeni ile acil servise başvuran çocuk hastalarda mezenterik lenfadenit (ML) sık rastlanır. Bu çalışmanın amacı ultrasonografi (US) ile tanımlana ML'nın birliktelik gösterdiği karın patolojilerini belirlemektir. Gereç ve Yöntemler: Ortalama yaşı 9 olan 104'ü erkek toplam 158 hastanın klinik, laboratuar ve radyolojik bulguları tekrar değerlendirildi.

Bulgular: US ile tanımlanan ML en sık yerleşim yeri sağ alt kadrandı (\%86). ML en sık birliktelik gösterdiği patoloji \%50 oranında nonspesifik karın ağrısıydı (NSKA). ML ölçümlerinin, yerleşiminin cinsiyet, yaş ve karın patolojisi ile bağlantısı yoktu.

Sonuç: Çocuklarda acil servise başvuru gerektiren karın ağrısında, US ile yapılan karın incelemesinde saptanan ML saptanan tek bulgu olabilir. ML varlığı, NSKA ile ilişkili olabilir.

Anahtar Kelimeler: Karın Ağrısı, Mezenterik Lenfadenit, Ultrason, Çocuklar.

\section{Abstract}

Objective: Mesenteric lymphadenitis (ML) is common in pediatric patients admitted to the emergency room with abdominal pain. The aim of this study is to determine abdominal pathologies associated with ML defined by ultrasonography (US).

Materials and Methods: The clinical, laboratory and radiological findings of a total of 158 patients, 104 of whom were men, with a mean age of 9 , were re-evaluated.

Results: The most common location of ML defined by US was the right lower quadrant (86\%). The most common pathology with ML was nonspecific abdominal pain (NSAP) at a rate of 50\%. ML measurements and location did not correlate with gender, age, and abdominal pathology.

Conclusion: In abdominal pain that requires admission to the emergency service in children, ML detected in the abdominal examination performed by US may be the only finding detected. The presence of ML may be associated with NSAP.

Keywords: Abdominal Pain, Mesenteric Lymphadenitis, Ultrasound, Children.

\section{Giriş}

Acil servise başvuran çocuk hastalarda başvuru sebeplerinin başında karın kaynaklı patolojiler gelir. En sık nedenler arasında akut appendisit, mezenterik lenfadenit, üriner enfeksiyon, gastroenterit, sebebi saptanamayan nonspesifik karın ağrısı (NSKA) ve invaginasyon sayılabilir [1]. Fizik muayene ve laboratuar bulgularına ek olarak tanı ve ayırıcı tanı amacıyla radyolojik görüntüleme gerekebilir. $\mathrm{Bu}$ amaçla, radyoloji pratiğinde karın ultrasonografisi (US) 
sık tercih edilir [2]. Karın ağrısının sebebine yönelik sonografik incelemede, yüksek frekanslı lineer transduser ile yapılan ek değerlendirme ile mezenter içinde yerleşmiş lenf nodları gösterilebilmektedir. Mezenterik lenfadenit (ML) birincil (idiopatik) ya da ikincil (malignite ve enfektif süreç) nedenli olabilir [3]. Çocuk ve adelosanlarda erişkinlere göre daha sık klinik tablo oluşturur. Mezenterik lenf adenitin prevelansı bilinmemektedir [4].

$\mathrm{Bu}$ çalışmanın amacı, laboratuar bulgularının nonspesifik ve yol gösterici olmayan karından kaynaklanan rahatsızlıklar ile acil servise başvuran 18 yaş altındaki olgularda ML'nin birliktelik gösterdiği patolojileri saptamaktır. Tek merkez bulgularından elde edilen bilgiler ile ikincil amaç, günlük acil sonografi pratiğinde saptanan ML'lerin yorumlanmasına yol göstermektir.

\section{Materyal ve Metot}

Etik kurul izni alındıktan sonra ( TC Necmettin Erbakan Üniversitesi İlaç ve Tıbbi Cihaz Dışı Araştırmalar Etik Kurulu; 19.02.2021;2021/3108) hastanemiz Çocuk Acil Servis'e Ocak 2020-Ocak 2021 tarihleri arasında karın ağrısı, huzursuzluk, kusma, ateş, hassasiyet, fizik muayenede karında lokalize ya da yaygın defans saptanan, istemli defans bulunan, laboratuar bulgularının nonspesifik ve yol gösterici olmayan, radyolojik görüntüleme gereği duyulan 18 yaş altındaki çocuk hastalar çalışmaya dahil edildi. Acil serviste tanıya ulaşmak için, kendini ifade edemeyen yaştaki çocuk olguların aileden alınan öyküleri ve fizik muayene bulguları kullanılmıştı. Bu olgulardan travma ve cerrahi öyküsü, saptanmış genetik ve ailesel hastalığı olan, hematolojik ve onkolojik tanısı olan çocuk hastalar çalışma dışı bırakıldı. Hastane işletim sistemine 'mezenterik lenfadenit, mezenterik lenfadenopati' anahtar kelimeleri girilerek sonografik rapor taraması yapıldı. Tam kan sayımında lökosit sayısı $10.000 \mu \mathrm{l} / \mathrm{ml}$ altında olan olgular çalışmaya kabul edildi. C reaktif protein serum seviyesi çoğu olguda yüksek olduğundan parametreler arasına alınmadı.

Fizik muayenelerinde ardından gerekli olgularda elde edilen ayakta ya da yatarak ön-arka karın radyogramlarında anlamlı ve yol gösterici bulgu olmayan olgulara US muayenesi yapılmıştı. Bu inceleme mesai saatleri içinde çoğunlukla çocuk radyolojisi uzmanı, nöbet saatlerinde radyoloji uzmanları tarafından değerlendirilmiştir. Tüm olgular $4-8 \mathrm{MHz}$ pediatrik konveks transduser ile yapılan US sonras1, $8-12 \mathrm{MHz}$ lineer dizilimli transduserler ile barsak duvarı, mezenter inflamasyon bulgularının değerlendirmesi yapılmıştı. Bulunan ana patolojinin yanında, lineer dizilimli transduser ile saptanan ML'nın lokalizasyonu, boyutu, radyolojik karakteri inceleme raporuna kaydedilmişti. Her biri $5 \mathrm{~mm}$ üzerinde uzun aksa sahip, üç veya daha fazla lenf nodundan oluşan bir küme varsa, mezenterik adenit mevcut kabul edildi [5]. ML saptanan hastalar seçilerek çalışmaya alınan çocuk hastaların cinsiyet, yaş, lenf nodu yerleşimi, en uzun boyu ile en kısa boyu, çocuk acil servisten ayrılırken aldıkları kesin tanı, tanımlanan lenf nodlarının sonografik kontrol incelemesinin yapılıp yapılmadığ kaydedildi. ML yerleşim yerleri olarak, US raporlarında en sık bildirilen sağ alt kadran, sol alt kadran, periumblikal ve yaygın yerleşim belirlendi. ML varlığı, yerleşimi, boyutları ile cinsiyet, yaş ve tanımlanan karın patolojisi arasındaki olası bağlantı araştırıldı.

Sonuçları değerlendirmek için, Kolmogorov-Smirnov testi kullanıldı. İki bağımsız grup için reddedilme durumunda Mann Whitney-U testi gibi parametrik olmayan testler; aksi takdirde, bir t-testi kullanılmıştır. Parametrik olmayan veriler için grup sayısı az olduğunda Kruskal-Wallis testi kullanıldı.

\section{Bulgular ve Tartışma \\ 3.1.Bulgilar}

Hastane kayıtlarından yapılan taramada belirlenen kriterlere uyan ve çalışmaya alınan çocukların sayısı 158 (104 erkek, $54 \mathrm{kız}$ ); yaş aralığı 0-18 yaş, yaş ortalamas $19,37 \pm 6,36$ yaş idi. Ortanca yaş 9,5 yaştı. ML ortalama uzun boyu $12,6 \pm 3,85 \mathrm{~mm}$, kisa boyu $6,2 \pm 2,08 \mathrm{~mm}$ idi. Ölçülen tüm lenf nodlarının uzun boyları, kısa boylarından fazlaydı; ovoid şekil korunmuştu. ML yerleşimi, lenf nodunun uzun boyu, kısa boyu ile cinsiyet arasında bağlantı saptanmadı (sirasiyla $\mathrm{p}=0,51, \mathrm{p}=0,62$ ve $\mathrm{p}=0,65$ ). Bu parametreler ile yaş arasında istatistiksel anlamlı bağlantı yoktu (sirasiyla $\mathrm{p}=0,12, \mathrm{p}=0,15$ ve $\mathrm{p}=0,27$ ). Lenf nodlarının uzun ve kısa boyu oranı ortalaması tüm olgularda $2,62 \pm 0,85 \mathrm{~mm}$ idi. Bu oran ile cinsiyet, yaş ve olgunun kesin tanısı arasında bağlantı bulunmadı (sırasıyla $\mathrm{p}=0,25, \mathrm{p}=0,38, \mathrm{p}=0,18)$.

Sonografik olarak saptanan en sık ML yerleşim yeri sağ alt kadran, çekal bölge komşuluğu idi (\%84). Yerleşim yerlerine göre dağılım Tablo.1'de verilmiştir.

Tablo. 1 Mezenterik lenf nodlarının yerleşim yerleri.

\begin{tabular}{|l|c|c|}
\hline Yerleşim & N & $\%$ \\
\hline Să̆ Alt Kadran & 134 & $\mathbf{8 4 , 6}$ \\
\hline Sol AltKadran & 4 & 2,8 \\
\hline Periumblikal & 3 & 1,8 \\
\hline Yaygın & 17 & $\mathbf{1 0 , 8}$ \\
\hline
\end{tabular}

Lenf nodu uzun ve kısa boyutu ile yerleşim yeri arasında arasında istatistiksel anlamlılık oluşturan bağlantı yoktu (sırasıly $\mathrm{p}=0,24$ ve $\mathrm{p}=0,36$ ).

US ile saptanan ML ile en sik birliktelik gösteren abdominal patoloji NSKA (\%50). Bu olgularda fizik muayene, laboratuar sonuçları ve radyolojik değerlendirme ile neden olan patoloji gösterilememiş, klinik bulgular 12 saat içinde gerilemiş ve yakınmalar ortadan kalkmıştı. Ardından gelen tanı şaşırtıcı olmayan şekilde akut appendisit idi. ML ile birliktelik gösteren diğer tanılar Tablo. 2'de gösterilmiştir.

Tablo 2. Mezenterik lenf nodu saptanan çocuk olgularda konulan ve tedavi düzenlenen klinik tanılar. 


\begin{tabular}{|l|l|l|}
\hline Verilen Tanı & N & \% \\
\hline Malnutrisyon & 1 & 0,7 \\
\hline ÜSYE & 3 & 1,7 \\
\hline Konstipasyon & 4 & 2,7 \\
\hline İnvaginasyon & 8 & 5 \\
\hline Meckel Dv & 1 & 0,7 \\
\hline Parazitoz (ascaris) & 2 & 1,4 \\
\hline Kusma & 1 & 0,7 \\
\hline Subfebril Ateş & 2 & 1,4 \\
\hline NSKA & 79 & 50 \\
\hline G1da intoks. & 1 & 0,7 \\
\hline AGE & 3 & 1,7 \\
\hline Aku appendisit & 38 & 24 \\
\hline GIS yb csm & 1 & 0,7 \\
\hline Terminal ileit & 6 & 3,6 \\
\hline Ürolitiazis & 4 & 2,5 \\
\hline İdrar Yolu Enfk & 4 & 2,5 \\
\hline ÜSYE: Üst Solmm Yol Enfaiyon & & \\
\hline
\end{tabular}

(ÜSYE: Üst Solunum Yolu Enfeksiyonu, Meckel Dv: Meckel Divertiküliti, NSKA: Nonspesifik karın ağrısı, AGE: Akut Gastroenterit, GIS yb csm: Gastrointestinal sistemde yabancı cisim)

Akut appendisit tanılı tüm olgularda ML yerleşimi sağ alt kadranda, çekal bölgede idi. Öngörülebildiği gibi, ML yerleşimi ile tanı alan karın patolojisi arasında istatistiksel bağlantı vardı $(\mathrm{p}<0,05)$.

Tedavi sırası ya da sonrasinda sonografik olarak ML kontrol incelemesi yapılan çocuk olgu sayısı $9(\% 5,5)$ idi. Kalan 149 olguda, izlem veya tedavi sonrası US kontrol incelemesi yapılmamıştı.

\subsection{Tartışma}

Acil servise başvuran semptomatik çocuk hastalarda karından kaynaklı rahatsızlıkların ve fizik muayene bulgularının değerlendirilmesinde radyolojik inceleme desteği tanıya ulaşmak için yardımcıdır. Bu çalışmada çocuk hastalarda US ile saptanan ML'nin boyutları, yerleşimi ve birliktelik gösterdikleri karın patolojileri araştırıldı.

ML karın ağrısı ile kendini gösterebilir. Ancak her yönden sağlıklı çocuklarda da saptanabildiği bildirilmiştir. Altı yaşa kadar olan çocuklarda bir nedene bağlanamayan ML gelişebileceği, bu yaştan sonra ortadan kayboldukları saptanmıştır. Kısa boyu $8 \mathrm{~mm}$ ve $10 \mathrm{~mm}$ 'den uzun olan ML'nın semptom yarattıkları raporlanmıştır [6,7]. $\mathrm{Bu}$ çalışmada semptomatik çocuk hastalarda ML kısa boyu ortalamas1 $6,25 \pm 2,08 \mathrm{~mm}$ idi. NSKA tanis1 alan olgularda da en büyük kısa boy $12 \mathrm{~mm}$, en küçük kısa boy ise $3 \mathrm{~mm}$ bulundu. Özellikle küçük yaştaki olgularda başka nedeni bulunmayan karın kaynaklı yakınma ve bulguların olması, bu boyutlardaki ML'nın semptom yaratabileceğini düşündürmektedir.

ML'nin araştırılan radyolojik özelliklerinin, katılımcıların yaşı ve cinsiyeti ile bağlantısı yoktu. Bu

bulgu önceki çalı̧̧malar ile uyumluluk göstermektedir $[2,6,7]$. Çalışma örneklemindeki ML saptanan olguların yarısı NSKA tanısı aldı. NSKA bir dışlama tanısı kabul edilmekte olup, bir haftadan kısa süren, araştırmalara rağmen tanı konulamayan hem somatik hem de fonksiyonel tanı konulmamış durumların spektrumunu tanımlar [8]. Nonspesifik karın ağrısı erişkinde karın ağrısı tablolarının \%21'ini oluşturur, çocuklarda kesinleşmiş bir oran bulunamamıştır [9]. Çalışma kapsamındaki çocuk hastaların \%38'nde akut appendisit tanısı almıştı. Özdamar ve Karavaş [10], akut appendisit ve ML ayırıcı tanısinda US kullandıkları çalışmalarında ML'nın uzun ve kısa akslarının oranının ayırıcı tanıda değerli bir bulgu olduğu bildirilmiştir. $\mathrm{Bu}$ oranın $\mathrm{ML}$ olan olgularda, appendisit tanısı alan olgulara göre anlamlı derecede yüksek olduğunu saptanmışlardır. Çalışmamızda tüm olguların tanısının \%38'ini oluşturan appendisit kliniğinde saptanan ML boyutları, uzun ve kısa boylarının oranı arasında anlamlı farklılık bulunmadı. Bunun nedeni çalışmamızda appendisit oranının daha az olması olabilir.

Olgularda ML yerleşimi en sık sağ alt kadranda idi (\%84). Bu durum literatür bulguları ile uyumludur $[11,12]$. Yakın zamanda US'nın lenf nodu taramada başarısının kısıtlı olduğunu öne süren ve bilgisayarlı tomografi ile semptomsuz çocuk hastalarda lenf nodlarının boyut ve yerleşiminin araştırıldığı bir çalışmada batın içinde en sık lenf nodu yerleşim yerinin ileoçekal bölge çevresi olduğu bildirilmektedir [13]. Bu yerleşimin nedeni lenfoid doku aktivitesinin yüksekliği ve batın içi inflamatuar yanıt oluşturan patolojilerin ağırlıkla bu alanda ortaya çıkması olabilir. Sağlıklı erişkinlerde çok kesitli bilgisayarlı tomografi ile ML araştırılan bir çalışma, en sık yerleşim yerinin \%68 olguda mezenterik kök olduğu bildirilmiştir [14]. Diğer yerleşim yerleri $\% 17$ olguda yaygın, $\% 11$ sağ alt kadran olarak bildirilmiştir. Çalışmamızda mezenter kök US ile yeterli olarak değerlendirilemediğinden bu yerleşimde yer alan ML tanımlanamamış olabilir. Çalışmamızda ikinci sıklıkta yaygın yerleşim $(\% 10,8)$ üriner enfeksiyon, ürolitiazis, akut gastrenterit, invaginasyon, NSKA, konstipasyon, parazitoz ile birliktelik göstermekteydi. Sol alt kadranda yerleşimli ML $(\% 2,8)$ üçüncü sıklıktaki yerleşim yeriydi. Birliktelik gösterdiği patolojiler kusma, ürolitiazis, NSKA idi. Periumblikal bölge yerleşimi $(\% 1,8)$ dördüncü sıradaki yerleşim yeriydi. Meckel divertiküliti, gastrointestinal segmentteki yabancı cisim ve gida intoksikasyonunda saptand. Literatürde bu bulguların karşılaştııılabileceği bir çalışma bulunamadi.

Karın ağrısı ve tanımlanan diğer bulgularla incelenirken, ML saptanan çocuk olguların; 5'i uygun klinik oluşturmamış akut appendisit izlemi, 3'ü invaginasyon izlemi, 1'i Meckel divertikülitinde izlem için olmak üzere toplam 9'unda $(\% 5,5)$ kontrol US incelemesi yapılmıştı. Tek merkez gözlemine dayanan bu sonuçlara göre, klinisyenlerin US'da ML tanımını klinik tanı olarak yorumlamadıkları anlamı 
çıkarılabilir. Çalışmamızdaki olguların yarısının acil servis taburculuğunda aldıkları tanının NSKA olduğu düşünüldüğünde, oluşan tabloda ML'nın sonuç değil, sebep olabileceği öngörülebilir. Tibbi literatürde, günlük radyoloji uygulamalarında sik rastlanan bu sorun üzerine yapılmış bir çalıșma bulunmamaktadır. Çalışmamızın bazı sınırlamaları vardır. Uygulanan hasta seçim kriterleri nedeni ile hasta sayısı düşüktü. Ayrıca, çocuk olgularda daha az olsa da US'nin teknik sinırlandırmaları nedeni ile ML saptanmasında yetersizlik engellenememiş olabilir. Örneğin; mezenterik kök yerleşimli lenf nodları, barsak hareketi ya da lümenlerindeki gaz nedeni ile görülememiş olabilir. Bu sorunun ortada kaldırılması için bilgisayarlı tomografi ile görüntüleme yapılabilir [14]. Çocuk hastada radyasyon maruziyetini önlemek için gereksiz görüntülemeden kaçınmak unutulmaması gereken ilkedir. Bir diğer sınırlama olguları US ile değerlendiren radyologların kişisel deneyimlerinin eşit olmamasiydi. $\mathrm{Bu}$ nedenle her radyolog ML taramas1 yapmamış veya raporlarında ML tanımlamamış olabilir. Ayrica, over torsiyonu, inkarsere herni, ileus gibi acil ve çabuk cevap verilmesi gereken olgularda radyologlar ML taraması yapmamaktadır. Hastane kayıtlarında bu olguların US raporlarında ML tanımlaması bulunamamıştır. $\mathrm{Bu}$ nedenle, genelleme yapmak güçleşmektedir.

\section{Sonuç}

Sonuç olarak; çocuklarda acil servise başvuru gerektiren, fizik muayenenin sonuca ulaştıramadığ karın ağrısı, karında hassasiyet ve huzursuzluk varlığında, US incelemesinde saptanan ML saptanan tek bulgu olabilir. $\mathrm{Bu}$ çalışmanın sonuçlarına göre çocuklarda ML, NSKA ile ilişkili olabileceği sonucuna varılmıştır. $\mathrm{Bu}$ sonuç, tedavi öncesi ve sonrası bulguların karşılaştırılabileceği, daha geniş ve homojen örneklem ile yapılacak prospektif çalışmalar ile doğrulanmalıdır.

\section{Teşekkür ve Bilgilendirme}

Yazarlar çıkar ilişkisi olmadığını beyan eder.

Finansal destek yoktur.

\section{Referanslar}

1.Puylaert, J.B, van der Zant, F.M, Mesenteric lymphadenitis or appendicitis? American Journal of Roentgenology, $1995,165,490$

2.Kim, J.S, Acute abdominal pain in children, Pediatric Gastroenterology Hepatolology and Nutrition, 2013, 16, 219-24.

3.Macari, M, Hines, J, et al. Mesenteric adenitis: CT diagnosis of primary versus secondary causes, incidence, and clinical significance in pediatric and adult patients, American Journal of Roentgenology, 2002, 178, 853-8.

4.Helbling, R, et al., Acute Nonspecific Mesenteric Lymphadenitis: More Than No Need for Surgery, BioMedical Research International, 2017, 9784565 .

5. Macari, M, Hines, J, Balthazar, E, Megibow, A, Mesenteric Adenitis, American Journal of Roentgenology, 2002, 178, 4, 853-58.
6.Wang, W.G, Tian, H, et al., Enlarged mesenteric lymph nodes in children: a clinical analysis with ultrasonography and the implications, Nan Fang Yi Ke Da Xue Xue Bao, 2011, 31(3), 522-4.

7.Simanovsky, N, Hiller, N, Importance of sonographic detection of enlarged abdominal lymph nodes in children, Journal of Medical Ultrasound, 2007, 26, 581-4.

8.Carlucci, M, Beneduce, A.A, et al., Nonspecific Abdominal Pain, Emergency Laparoscopy, 2016, pp 73-78, Springer, Cham.

9.Hastings, R.S, Powers, R.D, Abdominal pain in the ED: a 35 year retrospective, American Journal of Emergency Medical, 2011, 29(7), 711-6.

10. Özdamar, M.Y, Karavaş, E, Acute mesenteric lymphadenitis in children: findings related to differential diagnosis and hospitalization, Archives of Medical Science, 2020, 16(2), 313-320.

11. Karami, M, Taki, M, Prevalence of lymph node and maximum short axis in traumatic patients, Journal of Research in Medical Sciences, 2018, 29, 23, 1 .

12. Rathaus, V, Shapiro, M, et al., Enlarged mesenteric lymph nodes in asymptomatic children: the value of the inding in various imaging modalities, British Journal of Radiology, 2005, 78, 30-33.

13. Spijkers, S, Staats, J.M, et al., Abdominal lymph node size in children at computed tomography, Pediatric Radiology, 2020, 50, 1263-70.

14. Lucey, B.C, Stuhlfaut, J.W, et al., Mesenteric lymph nodes: detection and significance on MDCT, American Journal of Roentgenology, 2005, 184(1), 41-4.

http://edergi.cbu.edu.tr/ojs/index.php/cbusbed isimli yazarın CBU-SBED başlıklı eseri bu Creative Commons Alıntı-Gayriticari4.0 Uluslararası Lisansı ile lisanslanmıştır.

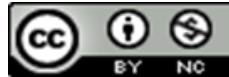

